\title{
Causes of Early Termination of University Studies in Relation to the Existence of Bridging Courses from the Perspective of Students and their Teachers
}

\author{
Renata Holubova*, Jana Slezáková \\ Department of Experimental Physics, Faculty of Science, Palacky University, 17.listopadu 12, 77146 Olomouc, Czech Republic
}

Received October 21, 2020; Revised November 27, 2020; Accepted December 20, 2020

\section{Cite This Paper in the following Citation Styles}

(a): [1] Renata Holubova, Jana Slezáková , "Causes of Early Termination of University Studies in Relation to the Existence of Bridging Courses from the Perspective of Students and their Teachers," Universal Journal of Educational Research, Vol. 8, No. 12B, pp. 8233-8239, 2020. DOI: 10.13189/ujer.2020.082627.

(b): Renata Holubova, Jana Slezáková (2020). Causes of Early Termination of University Studies in Relation to the Existence of Bridging Courses from the Perspective of Students and their Teachers. Universal Journal of Educational Research, 8(12B), 8233-8239. DOI: 10.13189/ujer.2020.082627.

Copyright@2020 by authors, all rights reserved. Authors agree that this article remains permanently open access under the terms of the Creative Commons Attribution License 4.0 International License

\begin{abstract}
The paper deals with the issue of early termination of university studies and summarizes the results of an international survey on the existence of bridging courses for high school graduates entering the 1st year of science studies. The introduction describes the current situation at universities and technical colleges, and points out a number of factors that cause early termination. Based on the analysis of student failures in the first year of undergraduate study of teacher training in science and mathematics, a research survey was conducted in the Czech Republic in cooperation with universities in Austria, Slovakia, Lithuania and Italy. The aim of the research was to describe and analyze the current state of the so-called bridging courses for students of natural sciences and to verify other possibilities of implementing these courses at participating universities. Within the survey, the method of qualitative research was used, and an induction procedure with the following phases was used: formulation of the research question, data collection, data evaluation and formulation of conclusions. In the end, the results of research at individual universities, including their analysis, are presented. At the same time, recommendations are given for the creation of further courses, namely in physics, chemistry and biology, which will be prepared within the international project ERASMUS + Bridge2Teach.
\end{abstract}

Keywords Study Failure, Bridging Course, Undergraduate Science Teachers

\section{Introduction}

Approximately $80 \%$ of high school graduates apply to universities. Approximately 65\% of these applicants are accepted [1]. Some of the universities (science faculties or technical universities) accept applicants without entrance exams. On the other hand there are specialisations with fields of study that register often several times more applicants than can be accepted. In recent years, universities, especially those with a technical focus, have faced the problem that students leave the university during their first year of study. University academics all over the world have been looking for reasons for dropping out of school and leaving university [2].

It is obvious that there are a wide number of reasons for dropping out of school and it is not just the insufficient professional readiness of high school students. Universities are trying to solve the situation in two main directions: 1. By expanding the offer of study fields (strengthening the motivation to study), 2. By including additional subjects into the study programs to help students bridge the gap between knowledge acquired in high schools and the requirements placed especially at the beginning of university studies during the first semester [3]. 


\section{Current State of the Studied Issues}

Study failure and its causes have been discussed in literature all over the world [4],[5],[6]. The OECD (The Organisation for Economic Co-operation and Development) study "Education at a glance" [7] states that about one third of students in the European Union countries drop out of university prematurely before graduation.

A number of foreign workplaces have been involved in the research of failure in the first semester of study. The results of their investigations can be summarized in the following parts of the text.

There are a number of factors influencing success in studying at the university, most of them acting simultaneously. These include teaching strategies, student motivation, students' approach to learning, contacts between students and academics, psychosocial aspects, expectations. Perhaps the most important have been the interest in the subject of study, motivation and discipline. None of these factors is directly related to the success of a high school student. Among the prerequisites for successful study was also included - not to be afraid to ask questions, willingness to work and graduate complementary courses. The reasons for failure are mainly as follows [8]: lack of desire to learn, a little enthusiastic lecturer, irregular feedback from the teacher, inability to work independently, substandard course management and study materials, inability to manage stress, insufficient background support (financial, family). Eikeland [9] states that the transition to university requires changes in many experienced ways of acting, in contact with teachers, classmates, the ability to learn on their own (own responsibility for studying) [9], [10]. During the first two years of the university study about $43 \%$ of students also failed the exam at least once, although more than $42 \%$ of them had excellent high school results. This is also one of the reasons for graduation - distrust of one's own ability, disappointment over oneself. A completely subjective aspect of the assessment is the complexity of preparation for learning - some students need up to twice the length of preparation for study compared to others while achieving the same study results. This can lead to a large workload and stress.

A great number of higher education graduates enter the university with different levels of professional knowledge and different motivations to study the given field. It is done due the admission without an entrance exam, the ignorance of the issues of the chosen field, and low motivation, especially to study university programs with a technical and scientific focus. The main problem for these students in terms of professional readiness is insufficient knowledge of mathematics and its application in physics, biology and chemistry [9], insufficient ability to study effectively and overcome stress. This problem can be solved at the university level, as mentioned above, by providing students with adequate help, study support and additional study materials. After overcoming the initial problems, these students often become quality university graduates and experts [11].

Majority of universities or high school institutions offer special courses for bridging the gap - the so called bridging courses, in the US these courses are called remedial courses [12].

According the lexicon, a bridging course is a short, focused learning programme designed to help high school students enter higher education institutions. The course is seen as an introductory level course and can range from six months to one year. The course is also created to prepare students for the pace and standard of tertiary education [13].

In our meaning bridging courses are short learning programmes designed to help students gain skills or knowledge needed for further or higher education (especially students who otherwise might not meet the usual entry requirements for a specific degree course).

In European environment these courses are less systematic; they are designed generally for one specific study program.

Based on the analysis of study failure during the first year of university studies of pre-graduate science teachers, a research survey was conducted in the Czech Republic in cooperation with universities in Austria, Slovakia, Lithuania and Italy. The aim of the investigation was to analyze the current state of so-called bridging courses for pre-graduate science teachers and check possible options for introducing such courses at the participating universities. The aim of these courses would be to facilitate the transition of students from high schools to university and to help successfully manage especially the first year of study at the university.

\section{Research Investigation}

Based on our previous activities in the field of improving the quality of pre-service teacher training the method of qualitative research was chosen [14], [15]. This method of research allows examining many aspects of the studied phenomenon with a relatively small number of respondents. An inductive procedure with individual stages was used: formulation of the research question, data collection, data evaluation and formulation of conclusions.

The research questions were formulated as follows:

1. What is the current status of existing bridging courses at the universtivies in Austria, Czech Republic, Slovakia, Italy and Lithuania?

2. What is the main cause of early termination of university studies?

The analysis was based on qualitative data obtained during a research survey at individual universities. 
Methods used for data collection:

1. Analysis of curricular documents of universities, the study programs.

2. Interviews with students - semi-structured interviews were applied with the possibility of using the benefits of a free interview.

3. Interviews with teachers who lecture to first-year science teacher students at universities.

The research survey took place during the school year 2019/2020 at universities in the Czech Republic, Austria, Lithuania, Italy and Slovakia within the international Erasmus ${ }^{+}$project Bridge2Teach (Developing Bridging Courses for Mathematics and Science Teacher Students). The study programs of faculties preparing future science teachers were analyzed in order to find out whether universities offer students in the initial phase of study additional, compensatory or repetitive courses aimed at summarizing and supplementing especially the high school curriculum. The analysis was performed at the following universities:

Austria - University of Vienna, University of Graz, University of Klagenfurt, Lithuania - University of Šauliai, Italy - University of Palermo, Slovakia - University of Nitra, Czech Republic - Palacky University Olomouc, Charles University Prague, University of South Bohemia, University of Ostrava, Masaryk University Brno.

Interviews with students (235 first-year students, 56 interviews with senior students) and teachers (31 teachers) were conducted at the above-mentioned universities. Inquiries via e-mail correspondence were also used.

\section{Results of the Research Survey}

\section{Research question 1:}

Bridging courses are offered by universities in Vienna, Lithuania, and additional seminars for first-year students are offered by universities in Slovakia and the Czech Republic. Universities in Italy are specific in that they offer refresher courses in secondary education only in the follow-up master's program in preparation for the teaching profession.

During the analysis of study plans, it was found that most of the courses offered are aimed at supplementing knowledge of mathematics, special bridging courses in physics, chemistry or biology are offered only by some universities (University of Šauliai, University of Vienna).

\section{University of Vienna}

University of Vienna offers for mathematics students the course Introduction to the Study of Mathematics and the Preparatory Course (in the range of 45 minutes per week). Classes run from early October to mid-December. The course ends with a compulsory exam. The course covers the topics: Language of Mathematics, Proof
Methods, Elementary Logic, Sets, Equivalences, Functions, Groups, Arrays, Numerical Systems, and Euclidean Algorithm.

For students of physics teaching, bridging courses Introduction to Physics and Preparatory Course are offered. Courses take place in the winter semester, they are not compulsory, but the final exam is compulsory, which is a condition for continuing the study.

The bridging course for chemistry students includes a Basic Laboratory Course and an Introductory Laboratory Practice. Both courses take place in both the winter and summer semesters. Both courses are compulsory. Students must first complete a preparatory tutorial (the first month of the semester), then they can continue their laboratory training (last two to three months of the semester). The aim for students is to acquire basic practical skills, principles of handling devices and substances, principles of work safety in a chemical laboratory.

Bridging courses Introduction to Biology and the lecture Introduction to Biology Teaching are offered for future biology teachers. The course Introduction to Biology takes place during the first four weeks of the semester. The course Introduction to Biology Teaching takes place in the first two months of the semester. The courses are not compulsory, but a final exam is compulsory as a condition for their further study.

\section{University of Lithuania}

The need to include bridging courses into the university study program is caused by the fact that high school students have only a limited number of teaching lessons of science subjects - in the last two years of the high school (grammar school) they choose only one of the science subjects or a science course. Consequently students with very different levels of knowledge from high schools enter the first year of the university. Students who did not learn physics, chemistry or biology at the grammar school are offered selected lectures to supplement their knowledge. A bridging course in science is also offered - it includes lectures, seminars, laboratory work and independent work of students. Other courses are not offered.

\section{Universities in the Czech Republic and Slovakia}

The Faculty of Science, University of Ostrava, as the only faculty that educates future physics teachers, has in its study program in the first semester the subject High School Mechanics - Revision of High School Physics. Only after passing the exam in this subject students can continue their studies in the second semester. In the second semester they are attending the subject Mechanics at the university level as a part of the basic course of physics.

All universities offer additional seminars in mathematics, both for future mathematics teachers and so as for students of science subjects. 


\section{Palacky University Olomouc}

A bridging physics course is not taught. For physics students, both in professional studies and for students of teaching, a great number of seminars in mathematics are offered. The content of these seminars are focused on teaching mathematical logic, functions, equations, coordinates, vectors, basics of differential and integral calculus, differential equations and the application of mathematical analysis in solving physical problems. An additional objective of this course is to deepen the knowledge of mathematics, learn the basics of working with software Mathematica, the software Matlab, and GNU Octave, and apply theoretical knowledge to solve physical problems.

\section{Research question 2:}

Given that most problems for first-year students are selected topics of mathematics, we have looked for the relationship between these problems and the content of the high school curriculum (grammar school curriculum) for the subject of mathematics.

According to the FEP G (Framework Educational Program for Grammar schools) [16], the teaching of mathematics at grammar schools develops and deepens the understanding of quantitative and spatial relationships of the real world, shapes the quantitative literacy of students and the ability of geometric insight. Mastering the required mathematical apparatus, elements of mathematical thinking, creating hypotheses and deductive reasoning are means for new deeper knowledge and a prerequisite for further study.

Mathematical education helps to develop abstract and analytical thinking, develops logical reasoning, teachers comprehensible and factual argumentation with the aim of finding objective truth rather than defending one's own opinion. The focus of teaching is on the acquisition of the ability to formulate a problem and the strategy of its solution, in the active mastery of mathematical tools and skills, in the cultivation of the ability to apply. Mathematics helps students to be able to evaluate the correctness of the procedure in deriving a statement and to reveal false conclusions. The expected outputs of the curriculum on functions state as follow: the student draws graphs of required functions (given by a simple function rule) and determines their properties, formulates and justifies the properties of studied functions and sequences uses knowledge about functions in solving equations and inequalities, applies relationships between values in determining quantitative relationships exponential, logarithmic and trigonometric functions and the relationships among these functions are modeled by the dependences of real events using known functions. The curriculum on differential and integral calculus is not included in the FEP G.

These generally formulated goals do not indicate the depth of knowledge acquisition. These special parts of mathematics mentioned above are the most problematic topics of the mathematics curriculum. They pose the gap the students have to bridge in the first semester of their university study.

It was founded out that one of the major problems of current first-year undergraduate students is not only the lack of needed knowledge but also the practical use of mathematical concepts and terminology. Many students know the procedures and algorithms of the solution, but they are unable to use mathematical language to clearly and comprehensibly explain their reasoning and correct solutions. This is also related to shortcomings in communicative skills, especially the ability to accurately explain the process of solving a mathematical problem and its correct comment.

Partial inaccuracies and shortcomings in basic concepts can be observed, for example, in one of the introductory chapters of high school mathematics. Students have a relatively frequent mixing of terms, the field of the variable, the conditions of existence of the expression and the definition field of the expression. Related to this a misunderstanding of the term expression occurs, which has several meanings in everyday life (external appearance reflecting an internal state, expression of an emotional or mental state, or it is also a mean of expression). Furthermore, it is obvious that students have problems with modifying algebraic expressions, especially modifying the expression to the product, further modifying the expression so that it does not contain a proportion, removing the square root of the denominator of the fraction and simplifying the expression to include as few numerical operations as possible.

A burning problem for high school graduates are the complex numbers, because most students encounter this topic only after entering the university. Knowledge of complex numbers is needed especially in physics, for example in the theory of the electromagnetic field.

Other shortcomings (of all types of high schools graduates) include a lack of understanding of the importance of analytical geometry and its relationship to synthetic geometry. Students have trouble converting a geometric problem to an algebraic problem and performing a calculation of a specific problem with subsequent backward geometric interpretation. It is the knowledge and subsequent application of analytical geometry that is needed mainly in physics, specifically in geometric optics. The key knowledge in analytical geometry is the concept of a vector, operations with vectors, and the concept of an unit vector. This concept is used, for example, to describe other vectors in physics, the graphical subtraction of vectors interprets the decomposition of force into components.

Students often do not understand functional dependences, such as the current dependence on voltage in a conductor, the dependence between masses and volume. They often miss the fact that functions can 
express the time course of a quantity. They cannot correctly determine the domain of a function, they do not know the rules for determining the domain of a function (the expression under the square root must be non-negative, the denominator of the fraction must not be zero, the logarithm is defined for positive numbers).

Both mentioned groups of students (graduates of grammar schools, secondary vocational schools) are not capable of a deeper perception of the connections between polynomials, functions, and equations. Students do not have interconnected knowledge of these parts of mathematics. They bring only isolated information and facts from high schools without a deeper understanding. This fact is becoming crucial in the training of future science and mathematics teachers.

The close connection between equations and functions is well explained to students on the example of exponential and inverse logarithmic functions. In addition, we find a number of applications in other natural sciences (eg the negatively taken decimal logarithm of oxonium cation activity more precisely defines the $\mathrm{pH}$ value, the term natural logarithm has meaning in the description of many natural processes, etc.). Logarithmic and exponential equations have a huge use in nuclear physics, where we can use them to determine how long it takes for a certain part of a radioactive sample to decay. Furthermore, using logarithmic equations, we can calculate, for example, the altitude of the place depending on the value of atmospheric pressure.

Another shortcoming that occurs in first-year undergraduate students' knowledge are the ideas of logic and the set theory. Students do not understand the language of logic, the construction of compound statements and their negations. They cannot work correctly with quantified statements and their negations. This manifests itself mainly in the proof of mathematical theorems or in determining the very structure of a mathematical theorem. High school teachers, who often draw only from textbooks, can also find the reason in the lack of explanation. However, in many cases they no longer meet current trends, for example they are not aimed at the development of key competencies or they are not fully in line with the FEP for individual types of high school studies.

In addition to the above reasons why first-year bachelor's students have problems with the above parts of mathematics, we can also mention the development of educational policy. In the 1970 s, around $10 \%$ of the population was admitted to university, and now the number has increased to more than $50 \%$. At the beginning of the 1990s, approximately $30 \%$ of primary school pupils went to grammar schools and vocational secondary schools. At present, the numbers of "good" students in high schools is roughly the same, but the average and below average have increased. Very similar is the situation at universities in Slovakia.

Table 1. summary of the current status of bridging courses (BC) for pre-graduate teachers of science subjects

\begin{tabular}{|c|c|c|c|c|c|}
\hline University & BC Math & BC Phys & BC Bio & BC Chem \\
\hline $\begin{array}{c}\text { University of } \\
\text { Vienna }\end{array}$ & $\begin{array}{c}2 \text { courses } \\
\text { Compulsory exam }\end{array}$ & $\begin{array}{c}\text { 1 course, } \\
\text { Compulsory exam }\end{array}$ & $\begin{array}{c}\text { 2 courses, } \\
\text { compulsory exam }\end{array}$ & $\begin{array}{c}2 \text { courses, } \\
\text { compulsory }\end{array}$ \\
\hline $\begin{array}{c}\text { University of } \\
\text { Lithuania }\end{array}$ & \multicolumn{3}{|c|}{ Selected lectures } & 1 course \\
\hline $\begin{array}{c}\text { Palacky University } \\
\text { Olomouc, CZ }\end{array}$ & $\begin{array}{c}2 \text { courses } \\
\text { optional }\end{array}$ & $\begin{array}{c}\text { Lectures within a } \\
\text { preparatory week }\end{array}$ & \\
\hline $\begin{array}{c}\text { University of } \\
\text { Palermo }\end{array}$ & \multicolumn{3}{|c|}{ BC not offered } \\
\hline
\end{tabular}




\section{Conclusions}

Based on the research survey, it is clear that the key role in the failure of students of science and mathematics in the first year of their study at universities is played by insufficient training in mathematics in terms of professional readiness. In the opinion of many teachers and principals of high schools, the introduction of a two-level curriculum (FEP, and school education programs), including the focus on the development of key competencies, is very debatable in the field of educational policy. The content of education is thus partially lagged behind. This is also related to the scope and content of the mathematics curriculum, which has adapted to the current state. The current concept of school-leaving examinations and the introduction and subsequent abolition of compulsory school-leaving examination in mathematics provokes almost endless discussions.

The research also shows that attention should be paid not only to the causes of dropping out due to lack of motivation, inability to study independently, work discipline and social background, but also to students learning. The different way of studying (learning) in the early stages of study and in the event of knowledge gaps, universities offer them various ways to overcome these difficulties. It can be beneficial to work out supporting materials for bridging courses in physics, chemistry, biology and mathematics, which would, in addition to factual information, also contain ideas for independent work and experimental activities. Selected parts of the curriculum could be included in existing seminars offered by individual schools in order to avoid the introduction of other subjects into the curricula.

If we analyze the answers of students from this survey, then they attach less need to refresher courses in chemistry, biology or physics. Only students in Lithuania find bridging courses in all science subjects as necessary. Students in Italy recommended the inclusion of refreshing courses in study programs of science teachers in the beginning of their master's stage of study (before their pedagogical practice). The basic problem for the study of science subjects is the knowledge of the necessary mathematical apparatus. Students would welcome bridging courses in mathematics before the beginning of the first semester. Especially in physics, students face insufficient knowledge of mathematics, when a mathematical problem overshadows the physical nature of the phenomenon being studied. From the point of view of the lecturers, it would be appropriate to include into the study program a bridging course (apart from mathematics) also in physics. Nowadays in most high schools physics is not taught in the last study year and only a negligible number of students graduate in physics. It would be beneficial to include a bridging course in chemistry as well, focused mainly on mastering laboratory techniques. As part of the Bridge2Teach project, such courses will be prepared and offered to schools. The content of these courses will be as follow.

\section{Bridging course Mathematics:}

- Module 1 - Introduction and overview (A brief general introduction into mathematics. Particularly concentrate on what makes mathematics at university different from the way mathematics is taught to students in school. Also clarifying important terms (definition, proof, theorem, etc.). An overview of the various fields of mathematics; also why we chose the following topics.)

- Module 2 - Basic concepts (Logic, sets and number theory. Geometry. Vectors. Linear and quadratic equations. Introduction to functions (first part of unit limits and derivatives, i.e. the explanation of what a function is).

- Module 3-Functions (Linear and quadratic functions (can be an extension of linear and quadratic equations). Exponential and logarithmic functions. Trigonometric. Functions. Limits and derivatives (and maybe integrals).

- Module 4 - Tools for real life (Probability and statistics. Linear Optimization.)

Bridging course Science:

- Modul 1 - Chemistry (Chemical calculations - their understanding (solution preparation, calculations from chemical equations, mass...). Work with the periodic table of elements. Oxidation-redox processes, reactions (electron exchange in redox reactions, compilation of redox equations...)

- Laboratory work - problems - measurement of volumes, preparation of solutions, filter....

- Modul 2 - Biology (The cell, organelles. Simple organisms - viruses and bacteria. Photosynthesis.)

- Modul 3 - Physics (Nature and Man. Nature research - explorations. Modern natural sciences about the micro-, macro-, and mega-worlds. Modern natural sciences about living nature. Contemporary natural sciences and human origin. Perspectives of natural sciences in the 21st century.)

These courses will be offered to various institutions, the documentation will be available at www pages of the Bridge2Teach project. The modules of the bridging course are designed to effectively address knowledge shortcomings of pre-graduate science teachers in the first term of their university studies.

\section{Acknowledgement}

This article was prepared with the support of the ERASMUS+ Project $\mathrm{N}^{\mathrm{o}}$ 209-1-AT01-KA203-051222 Developing Bridging Courses for Mathematics and Science Teacher Students (Bridge2Teach). 


\section{REFERENCES}

[1] Řezanka, M., "Studentů na vysokých školách v České republice ubývá”, Satistika a my, 1.4.2020, https://www.statistikaamy.cz/2020/04/01/studentu-na-vyso kych-skolach-v-ceske-republice-ubyva/ (accesed Jan. 30, 2020)

[2] The National Economic and Social Forum, "Early School Leavers“, FORUM REPORT, 24., Dublin Stationery Office 2002,http://files.nesc.ie/nesf_archive/nesf_reports/N ESF_24.pdf (accesed Oct. 10, 2020)

[3] Mateju, P., Simonová, N., Strakova, J., "Výzkum studentů prvních ročníků vysokých škol v České republice”, 2005, https://www.researchgate.net/publication/313373397(acces sed Oct. 10. 2020)

[4] Dale, R., "Early School Leaving”, Europian Commission Network of Experts in Social Sciences of Education and Training, 2010, https://www.spd.dcu.ie/site/edc/documents /nesse2010early-school-leaving-report.pdf (accesed Oct. 10, 2020)

[5] Doll, J. J., Eslami, Z., Walters, l., "Understanding why students drop out of high school, according to their own reports: are they pushed or pulled, or do they fall out? A comparative analysis of seven nationally representative studies”. SAGE open, 2013(3), DOI:10.1177/21582440135 03834

[6] Hloušková, L., "Mám základní vzdělání - Př́činy a důsledky předčasných odchodů ze studia a ze vzdělávání“, Studia paedagogica, vol. 19, no. 2, pp. 11-38, 2014. On-line http://www.phil.muni.cz/journals/index.php/studia-paedago gica/article/view/734/828

[7] OECD, "Education at a Glance“, on-line http://www.oecd.o rg/education/skills-beyond-school/educationataglance2007home.htm (accessed Oct.10, 2020).
[8] Frase, W.J., Killen R., "Factors influencing academic success or failure of first-year and senior university students: do education students and lecturers perceive things differently?” South African Journal of Education, vol. 23, no. 4, pp. 254 - 260, 2003.

[9] Eikeland, O.J., Manger, T., "Why Students Fail during Their First University Semesters”, International Review of Education vol. 38, no. 5, pp. 489-503, 1992.

[10] Finn, J. D., "Withdrawing from school”, Review of Educational Research, vol. 59, no. 2, pp. 117-142, 1989.

[11] Pospiech, G., Eylon, B., Bagno, E., Lehavi, Y., Marie-Annette Geyer M.A., "The role of mathematics for physics teaching and understanding”, IL NUOVO CIMENTO 38 C, pp. 110 -116, 2015.

[12] Büchele, S., "Bridging the gap - how effective are remedial Math Courses in Germany? “, MAGKS Joint Discussion Paper Series in Economics, University Marburg, No. 25-2018.

[13] Lexico: UK dictionary,https://www.lexico.com/definition/b ridging_course (acceesd Nov. 24, 2020).

[14] Holubova, R., "The Innovation of Physics Teacher Training at the Palacky University: Physics Teacher in the Czech Republic“, International Journal of Learning, vol. 14, no. 2, pp. 41-46, 2007.

[15] Holubova, R., "The Analysis around Strategies How to Engage Generation Y Learners”, American Journal of Educational Research, 2015, vol. 3, no. 5, pp. 624-630, 2015, DOI:10.12691/education-3-5-15.

[16] “Rámcový vzdělávací program pro gymnázia”, Výzkumný ústav pedagogický v Praze, 2007, http://www.vuppraha.rvp. cz/wp-content/uploads/2009/12/RVPG-2007-07_final.pdf (accessed Oct. 10, 2020). 